7. Reprod. Fert. (1974) 36, 177-187

\title{
EFFECT OF ORAL CYPROTERONE ACETATE ON URINARY AND SERUM FSH AND LH LEVELS IN ADULT MALES BEING TREATED FOR HYPERSEXUALITY
}

\author{
JANET BROTHERTON* \\ Schering Chemicals Ltd, Burgess Hill, Sussex, and School of Biological Sciences, \\ University of Sussex
}

(Received 12th February 1973)

\begin{abstract}
Summary. A group of eighteen male hypersexual patients received $50 \mathrm{mg}$ cyproterone acetate orally twice a day. Radioimmunoassays of $\mathrm{LH}$ and FSH were carried out at intervals on serum and 24-hr urine specimens. All the six 'pretreatment' and twenty-eight 'during-treatment' levels of urinary FSH fell within the normal range of 2 to 17 i.u. 2nd IRP-HMG/24 hr. One of the six 'pretreatment' and three of the twentyeight 'during-treatment' levels of urinary LH were higher than the normal range of 4 to $50 \mathrm{i} . u$. 2nd IRP-HMG/24 hr. Treated as a whole, the LH levels could be regarded as showing no difference due to treatment with cyproterone acetate but if the patient with the high pretreatment level, who was also suffering from schizophrenia, was removed from the group then the LH levels during treatment showed a significant rise. The mean serum LH was $6.3 \mathrm{mU}$ MRG $69 / 104$ standard/ml with an upper limit of $14.4 \mathrm{mU}$ and the mean serum FSH was 13.3 mi.u. 2nd IRP-HMG/ml with a range of 6 to 33 mi.u. All these results were within the quoted normal ranges. The mechanism of action of cyproterone acetate is discussed, taking into consideration the normal $\mathrm{LH}$ and FSH levels, low testosterone levels and inhibition of spermatogenesis and is compared with the actions of oestrogens, androgens, 'pure' progestagens and 'pure' anti-androgens on these parameters.
\end{abstract}

\section{INTRODUCTION}

Initial studies on the treatment of male hypersexuality with anti-androgens were with cyproterone rather than its acetate. It was discovered that cyproterone was a 'pure' anti-androgen, lacking the feedback suppression of gonadotrophin levels possessed by most compounds with progestational activity. The net effect was an increase in plasma testosterone and in FSH and LH levels (Rausch-Strooman, Petry, Hocevar, Mauss \& Senge, 1970; Vosbeck \& Keller, 1971; Brotherton, 1972). This is believed to be due to the direct prevention of androgenic feedback to the hypothalamus, so that more gonadotrophins are produced and hence more testosterone.

* Present address : Department of Chemotherapy, Schering A.G., I Berlin 65, Germany. 
Current investigations are being carried out exclusively with cyproterone acetate which has strong progestational and antigonadotrophic properties in addition to its anti-androgenic action. This compound has been used experimentally since 1967 for the treatment of hypersexuality in adult males (Laschet \& Laschet, 1967). Its use is known to be associated with a gradual reduction in libido and potency while spermatogenesis is also inhibited. By about 6 weeks of treatment, there is absence of ejaculate though there are no pathological changes in the testes. This contrasts with the testicular changes produced by pituitary suppression with androgens or oestrogens (Laschet \& Laschet, 1971; Cooper, Ismail, Phanjoo \& Love, 1972). The reduction in libido and potency takes place before the failure of spermatogenesis and returns more quickly after the cessation of treatment. This may be a reflection of the long delay of about 64 days for the complete cycle of spermatogenesis in man. Hormone assays have consistently shown that plasma testosterone levels are significantly reduced (Schoonees, Schalch \& Murphy, 1971; Sorcini, Sciarra, di Silverio \& Fraioli, 1971). The reduction in plasma testosterone may be as much as $50 \%$ in the first 5 days of therapy. A simultaneous rise in plasma androstenedione has been detected by Sorcini et al. (1971) which may be a manifestation of the local anti-androgenic action of cyproterone acetate. The effects of cyproterone acetate on gonadotrophins is less clear and the present study was specifically designed to measure the effects on LH and FSH levels.

\section{METHODS}

A group of eighteen male hypersexual patients from three clinical centres received $50 \mathrm{mg}$ cyproterone acetate orally twice a day. All the patients had normal sexual characteristics and were adults aged 22 to 54 years, except for patients B. 6 and B.10 who were 14 years old and suffering from Down's syndrome. Patients A.1, A.2 and A.3 were classed as manic-depressive, patients C.1, C.2 and C.3 showed a variety of aggressive sexual deviations and patient A.4 was suffering from schizophrenia. All the remaining patients were mentally subnormal. All the patients had either drawn the attention of the police to their abnormal hypersexual behaviour or were causing a sexual nuisance in a residential home for the mentally retarded.

At the start of this study, the precise nature of the episodic and diurnal fluctuations in plasma LH and FSH were not known and it was decided to estimate these gonadotrophins in $24-\mathrm{hr}$ urine specimens after storage at $-20^{\circ} \mathrm{C}$ until a batch had been accumulated. Radioimmunoassays of FSH and LH were carried out on extracts prepared by the method of Butt \& Lynch (1971). Some published normal values with ranges for these assays are shown in Table 1: the results obtained by the present methods are believed to fall within these ranges.

Later, serum gonadotrophin levels were estimated. Human pituitary FSH (preparation CPDS/3) containing approximately 5000 i.u./mg by bioassay (W. R. Butt, personal communication) and human pituitary $\mathrm{LH}$ were iodinated by the method of Butt (1972). The antisera were prepared in rabbits and the free and bound fractions were separated by the double antibody method. The 
standard for the urinary assays was the 2nd IRP-HMG: the same standard and MRC 69/104 were used for assays on blood. The MRC 69/104 standard was assumed to have a potency of 10 i.u. FSH and 25 i.u. LH/ampoule, each ampoule being equivalent to the immunoreactive $\mathrm{FSH}$ and $\mathrm{LH}$ in $0.5 \mathrm{mg}$ of the NIH standard LER-907 from which it is derived (Bangham \& Borth, 1972). At first, the inhibition curves for preparation MRC 69/104 were not strictly parallel to those of serum samples in the FSH immunoassay and results are therefore quoted in terms of mi.u. 2nd IRP-HMG. Latterly, the slopes approached parallelism and each mU MRG 69/104 was found to be equivalent

Table 1. Normal male urinary gonadotrophin levels by radioimmunoassay

\begin{tabular}{|c|c|c|c|c|c|}
\hline & $n$ & Mean & $\begin{array}{l}\text { Standard } \\
\text { deviation }\end{array}$ & Range & Reference \\
\hline FSH & 19 & $8 \cdot 5$ & $3 \cdot 6$ & 3 to 17 & Raiti et al. (1969) \\
\hline LH & $\begin{array}{r}10 \\
220\end{array}$ & $\begin{array}{l}31 \cdot 3 \\
23 \cdot 9\end{array}$ & $\begin{array}{l}10 \cdot 3 \\
15 \cdot 5\end{array}$ & $\begin{array}{r}17 \text { to } 50 \\
4 \text { to } 45\end{array}$ & $\begin{array}{l}\text { Baghdassarian et al. (1970) } \\
\text { Wikramanayake et al. (1972) }\end{array}$ \\
\hline \multicolumn{3}{|c|}{$\begin{array}{l}\text { After hypophysectomy } \\
\text { FSH }(n=7) \\
\text { LH }(n=7)\end{array}$} & & $\begin{array}{l}1.0 \text { to } 2 \cdot 2 \\
1 \cdot 4 \text { to } 2 \cdot 8\end{array}$ & Mancini et al. (1971) \\
\hline
\end{tabular}

Urinary gonadotrophin levels expressed in terms of i.u. 2nd IRP-HMG/24 hr.

Table 2. Normal serum FSH and LH levels in males by radioimmunoassay

\begin{tabular}{|c|c|c|c|c|c|}
\hline & Units & $n$ & Mean $\pm S . D$. & Range & Reference \\
\hline FSH & mi.u. 2nd IRP-HMG/ml & $\begin{array}{r}27 \\
230 \\
19\end{array}$ & $\begin{array}{l}17 \\
11 \cdot 00 \pm 0 \cdot 34 \\
7 \cdot 4 \pm 1 \cdot 9\end{array}$ & $\begin{array}{l}4 \text { to } 42 \\
2 \text { to } 13\end{array}$ & $\begin{array}{l}\text { Saxena et al. (1969) } \\
\text { Lee et al. (1970) } \\
\text { Baghdassarian et al. (1970) }\end{array}$ \\
\hline LH & $\begin{array}{l}\text { mi.u. 2nd IRP-HMG/ml } \\
\text { mi.u. LER } 907 / \mathrm{ml} \\
\mu \text { g LER } 907 / 100 \mathrm{ml}\end{array}$ & $\begin{array}{r}234 \\
27 \\
10 \\
40 \\
48 \\
8\end{array}$ & $\begin{array}{c}11 \cdot 11 \pm 0 \cdot 25 \\
10 \cdot 9 \pm 4 \cdot 0 \\
12 \cdot 0 \pm 4 \cdot 0 \\
4 \cdot 3 \pm 0 \cdot 4 \\
4 \cdot 5 \pm 3 \cdot 0\end{array}$ & $\begin{array}{l}2 \text { to } 32 \\
6 \text { to } 23 \\
4 \text { to } 20 \\
1 \text { to } 13 \\
3 \text { to } 7\end{array}$ & $\begin{array}{l}\text { Lee et al. (1970) } \\
\text { Saxena et al. }(1969) \\
\text { Baghdassarian et al. (1970) } \\
\text { Kolodny et al. (1972) } \\
\text { Rosen \& Weintraub (1971) } \\
\text { Faiman \& Winter (1971) }\end{array}$ \\
\hline
\end{tabular}

to 5 mi.u. 2nd IRP-HMG. In the LH assay, $1 \mathrm{mU}$ MRC 69/104 standard was equivalent to about 4 mi.u. 2nd IRP-HMG. Cross-reaction by FSH in the LH radioimmunoassay was insignificant and cross-reaction by $\mathrm{LH}$ in the FSH estimation was not more than $5 \%$. Normal quoted values, with ranges, for these assays are shown in Table 2. Normal results for the present methods are $8 \cdot 1 \pm$ 3.4 mi.u. 2nd IRP-HMG/ml (mean \pm S.D.) with a range of 4 to 15 for FSH (sixteen samples) and $6.0 \pm 4.7 \mathrm{mU}$ MRC $69 / 104$ standard $/ \mathrm{ml}$ with a range of 2.5 to 19.0 for LH (twenty-six samples).

\section{RESULTS}

Urinary levels

Tables 3 and 4 show the LH and FSH levels respectively in 24-hr urine 
specimens. Some pretreatment values were not available as the clinical trial had already started before hormone assays were arranged. The normal range of urinary FSH may be taken as 2 to 17 i.u. 2nd IRP-HMG/24 hr (Table 1). All the 'pretreatment' and all but two of the 'during-treatment' values fell within this range. Two of the 'during-treatment' values were slightly above the

Table 3. Urinary LH levels in hypersexual males

\begin{tabular}{l|c|c|c|c|c|c|c|c|c|c}
\hline & & \multicolumn{7}{|c}{ Weeks (w) or months (m) of treatment } \\
$\begin{array}{c}\text { Case } \\
\text { no. }\end{array}$ & $\begin{array}{c}\text { Before } \\
\text { treatment }\end{array}$ & $1 w$ & $2 w$ & $1 m$ & $2 m$ & $3 m$ & $<6 m$ & $6 m$ & $9 m$ & $12 m$ \\
\hline A.1 & 5.7 & & & $\begin{aligned} 12.0 \\
8.8\end{aligned}$ & & & 8.0 & 6.8 & & 4.8 \\
A.2 & & & & 8.8 & & & 5.5 & 52.6 & & 71.5 \\
A.3 & & & 11.3 & & & & & 33.9 & & 9.9 \\
A.4* & 104.0 & 33.6 & & & & & & 54.6 & 60.2 & 23.4 \\
B.1 & & 46.8 & & & & & & & & \\
B.2 & & & & & 11.4 & & & & & \\
B.3 & 22.0 & & 4.3 & & 7.0 & & & & & \\
B.4 & 4.7 & & & & & 7.8 & & & & \\
C.1 & 16.5 & 10.6 & & 13.1 & & 5.5 & & 99.8 & 15.9 & 8.9 \\
C.2 & 6.1 & 16.5 & & 11.0 & & & & & & \\
C.3 & & & & & & & & & \\
\hline
\end{tabular}

Urinary LH levels expressed in terms of i.u. 2nd IRP-HMG/24 hr.

Mean, before treatment $26.5 \pm 35.2$ (S.D.); mean, during treatment $23.4 \pm 24 \cdot 1$ (S.D.). * Schizophrenic.

Table 4. Urinary FSH levels in hypersexual males

\begin{tabular}{|c|c|c|c|c|c|c|c|c|c|c|}
\hline \multirow{2}{*}{$\begin{array}{l}\text { Case } \\
\text { no. }\end{array}$} & \multirow{2}{*}{$\begin{array}{c}\text { Before } \\
\text { treatment }\end{array}$} & \multicolumn{9}{|c|}{ Weeks (w) Ior months ( $m$ ) of treatment } \\
\hline & & $1 w$ & $2 w$ & $1 m$ & $2 m$ & $3 m$ & $<6 m$ & $6 m$ & $9 m$ & $12 m$ \\
\hline A.1 & $10 \cdot 2$ & & & $\begin{array}{l}11 \cdot 9 \\
10.4\end{array}$ & & & $\begin{array}{l}5 \cdot 6 \\
7.2\end{array}$ & & & $7 \cdot 8$ \\
\hline $\begin{array}{l}\text { A. } 2 \\
\text { A.3 } \\
\text { A. } 4^{*}\end{array}$ & $17 \cdot 2$ & $\begin{array}{r}8.5 \\
23.5\end{array}$ & $9 \cdot 3$ & & & & & $\begin{array}{r}12 \cdot 4 \\
9.4 \\
11.6\end{array}$ & $14 \cdot 3$ & $\begin{array}{r}19 \cdot 5 \\
5 \cdot 6 \\
10 \cdot 3\end{array}$ \\
\hline $\begin{array}{l}\text { B. } 1 \\
\text { B. } 2 \\
\text { B.3 } \\
\text { B.4 }\end{array}$ & $5 \cdot 8$ & & $<3 \cdot 1$ & & $\begin{array}{l}5 \cdot 8 \\
5 \cdot 2\end{array}$ & $7 \cdot 1$ & & & & \\
\hline $\begin{array}{l}\text { C. } 1 \\
\text { C. } 2 \\
\text { C. } 3\end{array}$ & $\begin{array}{l}2 \cdot 6 \\
5 \cdot 5 \\
2 \cdot 6\end{array}$ & $\begin{array}{l}10 \cdot 9 \\
10 \cdot 0\end{array}$ & & $\begin{array}{l}9 \cdot 6 \\
4 \cdot 7\end{array}$ & & $4 \cdot 6$ & & $8 \cdot 1$ & $4 \cdot 5$ & $9 \cdot 5$ \\
\hline
\end{tabular}

Urinary FSH levels expressed in terms of i.u. 2nd IRP-HMG/24 hr.

Mean, before treatment $7 \cdot 32 \pm 5 \cdot 10$ (S.D.); mean, during treatment $9 \cdot 16 \pm 4 \cdot 40$ (S.D.).

* Schizophrenic.

normal range but this was not considered significant. The normal range for urinary LH is probably 4 to 50 i.u. 2nd IRP-HMG/24 hr (Table 1). One 'pretreatment' value, that of patient A.4, was significantly greater than this range at 104 i.u. but there was an isolated value of 99.8 i.u. in patient C.1 whose other values were all normal. There was a very wide spread of results 


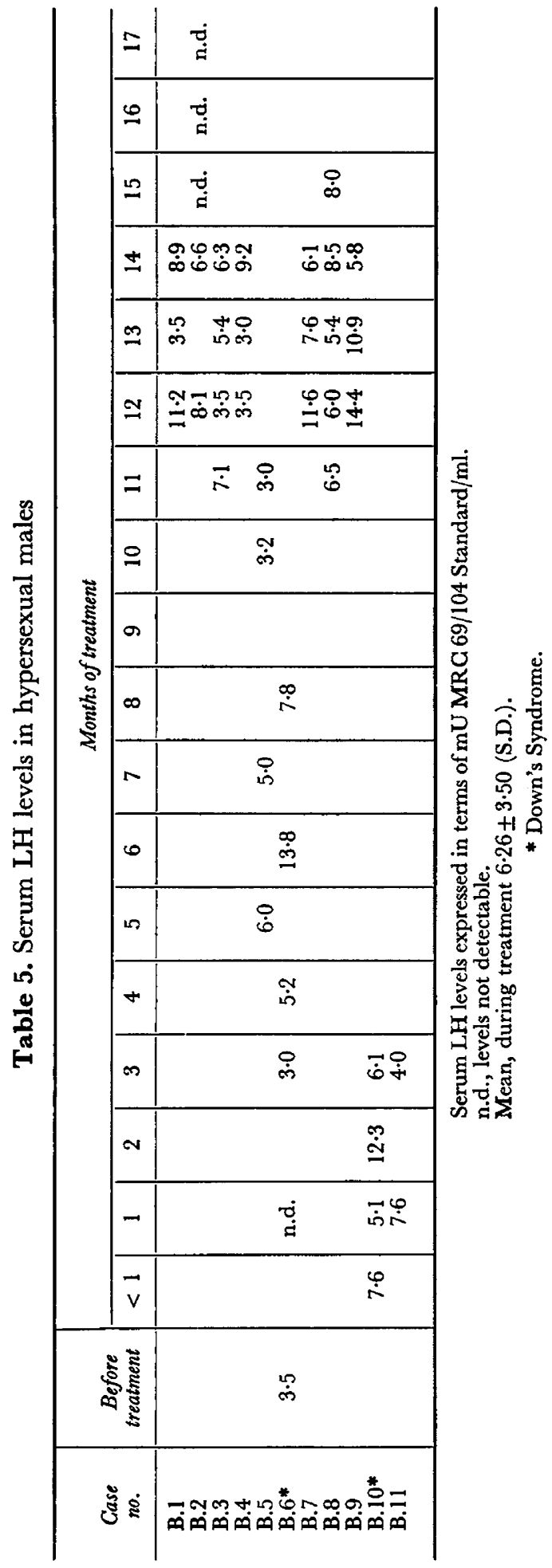


182

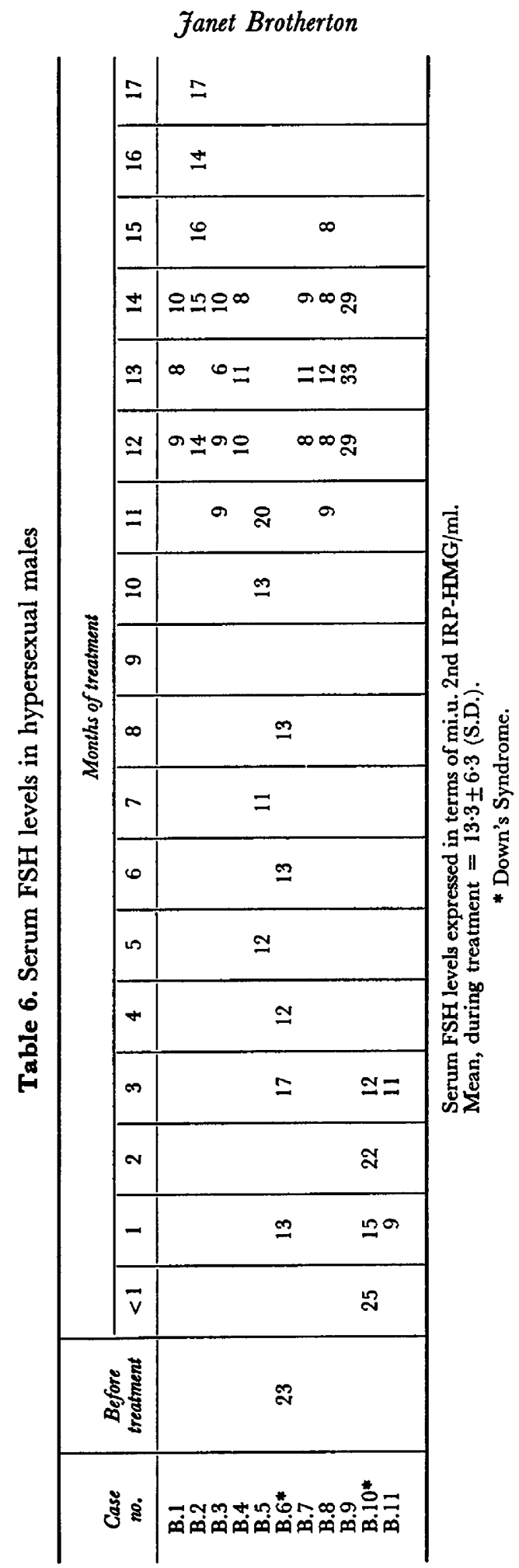


for both FSH and LH values and there was no evidence for a trend towards lower or higher values as treatment progressed. No single value was as low as the levels achieved after hypophysectomy (Mancini, Vilar, Donini \& Lloret, 1971).

Treated as independent groups, the six 'pretreatment' and twenty-eight 'during-treatment' values showed no statistically significant difference (Croxton, Cowden \& Klein, 1968; Brotherton \& Harcus, 1973). The mean FSH level was $7 \cdot 32 \pm 5 \cdot 10$ i.u. ( \pm S.D.) pretreatment, compared with $9 \cdot 16 \pm 4.40$ i.u. ( \pm S.D.) during treatment and $8 \cdot 5 \pm 3 \cdot 6$ i.u. ( \pm S.D.) quoted by Raiti, Light \& Blizzard (1969). The mean LH was $26 \cdot 5 \pm 35 \cdot 2$ i.u. ( \pm S.D.), compared with $23 \cdot 4 \pm 24 \cdot 1$ i.u. ( \pm S.D.) during treatment and $23 \cdot 9 \pm 15 \cdot 5$ i.u. ( \pm S.D.) quoted by Wikramanayake and his co-authors (1972).

It is possible that patient A.4 should be removed from the series of urinary results. Some patients suffering from schizophrenia have been shown to exhibit a degree of testicular damage (Hemphill, Reiss \& Taylor, 1944). Primary testicular failure is usually associated with raised gonadotrophin levels and the initial LH for patient A.4 was very high. If all the results for this patient are removed from the series, the mean 'pretreatment' $\mathrm{LH}$ level becomes $11.04 \pm 7.04$ i.u. ( \pm S.D.) and the mean 'during-treatment' value $19 \cdot 00 \pm 23 \cdot 40$ i.u. ( \pm S.D.). This difference is highly significant at the 0.001 level. Similarly, the mean 'pretreatment' FSH level becomes 5.34 $\pm 2 \cdot 79$ i.u. ( \pm S.D.) and the mean 'during-treatment' value $8 \cdot 19 \pm 3 \cdot 49$ i.u. ( \pm S.D.) which is significantly different at the 0.05 level. It seems that, by the removal of the one possibly aberrant result, there is a significant rise in urinary LH and FSH levels during treatment with cyproterone acetate.

\section{Serum levels}

Tables 5 and 6 show the LH and FSH levels, respectively, in serum obtained mostly after a long period of treatment. The mean serum $\mathrm{LH}$ was $6 \cdot 3 \pm 3 \cdot 5 \mathrm{mU}$ MRC 69/104 standard $/ \mathrm{ml}$ ( \pm S.D.) with a range of 0 to $14.4 \mathrm{mU} / \mathrm{ml}$. The mean serum FSH was $13.3 \pm 6.3$ mi.u. $/ \mathrm{ml}$ ( \pm S.D.), with a range of 6 to 33 mi.u./ml. It is possible that patients B. 6 and B. 10 should be removed from the series as reduced semen counts have been reported in adults suffering from Down's syndrome (Anon., 1972). When this was done, there was no significant effect on the mean serum LH and FSH levels in this group of patients. All the serum FSH levels are within the quoted normal range (Table 2). The serum LH levels also appear to be in the normal range, taking into account the variety of standards in common use and that factors from bioassays are required to convert to the equivalent values in terms of the 2nd IRP-HMG.

\section{DISCUSSION}

This is the largest and most abundant series of LH and FSH assay results for males being treated with oral cyproterone acetate and it is difficult to compare them with other reports. Sorcini et al. (1971) found no change in plasma LH or FSH by radioimmunoassay, but this was after only 3 days' treatment of two patients with $300 \mathrm{mg} /$ day in three doses. After 20 days' treatment of six patients with $200 \mathrm{mg}$ daily, Vosbeck \& Keller (1971) found only a slight 
lowering of the level in the urine of $\mathrm{LH}$ estimated by the OAAD bioassay method after the acetone-ethanol-ammonium acetate extraction procedure, but a much more significant lowering of FSH as estimated by the ovarian augmentation bioassay method. In a trial over 16 weeks in eight men in the age range 46 to 70 (mean, 64) years, given $100 \mathrm{mg}$ twice daily, Schoonees $\mathrm{et} \mathrm{al}$. (1971) found the maximum decrease in plasma testosterone occurred after 2 weeks of therapy, being about a tenth of the control level. There was then a rebound to a constant level of about $100 \mathrm{ng} / 100 \mathrm{ml}$ compared with the normal and control means of about $400 \mathrm{ng} / 100 \mathrm{ml}$. Plasma LH did not change significantly throughout the study but plasma FSH showed a decrease which was statistically significant in the 2nd and 4th weeks, but not in the 1st and 16th weeks. These three studies are consistent with the view that cyproterone acetate has no effect on LH levels and may produce a slight decrease in FSH levels. The studies reported here show no effect on either parameter but the dosage used was the smallest so far reported. It seems likely that the antigonadotrophic activity of cyproterone acetate is very weak and only exhibited at doses of 200 to $300 \mathrm{mg}$ daily.

By contrast, the antigonadotrophic activities of simple androgens and oestrogens are exhibited at much smaller doses, in that they exert a negative feedback action on the hypothalamo-pituitary axis so that gonadotrophin secretion is suppressed and hence testicular testosterone secretion is also suppressed. In very small doses, e.g. 30 to $50 \mu \mathrm{g}$ ethinylestradiol/day, oestrogens appear to inhibit FSH secretion more than LH secretion in women (Yen \& Tsai, 1971) and men (Reiter \& Kulin, 1972). During this treatment, FSH levels may decrease significantly but LH levels remain the same. In larger doses, oestrogens inhibit both LH and FSH secretion, both of which fall to basal levels. In addition to the failure of spermatogenesis, the testes show severe hyalinization.

In very small doses, androgens appear to inhibit LH secretion rather more than FSH secretion in men (Peterson, Midgley \& Jaffe, 1968; Lee, Jaffe, Midgley, Kohen \& Niswender, 1972). It is believed that androgens are the specific agent for the negative feedback on LH in men and there is a direct relationship between plasma testosterone and LH levels. In larger doses, both LH and FSH secretion are inhibited and the testes show hyalinization.

When progestagens are given to males and females, the dose required to cause an antigonadotrophic effect is much larger than for oestrogens and androgens. Some powerful progestagens, e.g. $17 \alpha$-hydroxyprogesterone caproate, appear to have no antigonadotrophic action in intramuscular doses of $250 \mathrm{mg}$ every 3 days, and this type of weak feedback action seems to apply to all the progestagens that are structurally related to progesterone, rather than derivatives of androstane and oestrane. Progesterone itself, as a 100-mg suppository five times daily for 9 days, was required to suppress plasma $\mathrm{LH}$ and testosterone levels to about half the control levels in four normal males (Sundsfjord, Aakvaag \& Norman, 1971). The general effect of the pregnane-type progestagens appears to be to suppress LH rather than FSH. This has been shown for medroxyprogesterone acetate in both males (Gordon and his co-authors, 1970) and in females receiving $150 \mathrm{mg}$ intramuscularly every 3 months (Goldzieher, 
Kleber, Moses \& Rathmacher, 1970). When large doses of medroxyprogesterone acetate, i.e. $50 \mathrm{mg}$ orally twice daily, were given to normal males, plasma testosterone levels only decreased to about half the control values while the simultaneous administration of the androgen, fluoxymesterone, in doses of $40 \mathrm{mg}$ daily, produced a further and greater decline in plasma testosterone levels (Kirschner \& Schneider, 1972).

It is now apparent that the effects of cyproterone acetate are different from those of a pure anti-androgen, i.e. cyproterone, and a pregnane-type progestagen without significant anti-androgenic effects, e.g. medroxyprogesterone acetate. It seems that the anti-androgenic component in cyproterone and its acetate is responsible for inhibition of the specific suppression of $\mathrm{LH}$ by androgen, so allowing the continued production of $\mathrm{LH}$ and, hence, of testosterone. The progestagenic component of cyproterone acetate appears to allow a partial suppression to normal values of the excess $\mathbf{L H}$ produced under anti-androgen alone, while the progestagenic potency of medroxyprogesterone acetate allows the direct suppression of LH to below normal values. It now seems that the suppressive effects of cyproterone acetate on libido and potency and on spermatogenesis can be achieved in the presence of normal LH and/or FSH levels.

The effect of cyproterone acetate on the testes, as shown by testicular biopsy, has been described by several workers (Ott, 1968; Markewitz, Veenema, Fingerhut, Nehme-Haily \& Sommers, 1969; Städtler, 1972) and the effect on the spermatozoa in the ejaculate, when that still exists, has been described by Ott \& Hoffet (1968). It is important to have pretreatment testicular biopsies for comparison as the proportion of males in mental hospitals who exhibit varying degrees of testicular atrophy is high (Johnson, 1968; Städtler, 1972) regardless of whether they are classified as suffering from schizophrenia or not. It is clear that, in previously normal males, the pathological changes induced in the testes are minimal. There is severe tubular atrophy with a narrowing of the germinal epithelium and loss of sperm-forming elements. Spermatogenesis is arrested at the stage of the spermatocytes and spermatids rarely form. There is atrophy of the Leydig cells which accounts for the decrease in plasma testosterone levels. These effects occur at $100 \mathrm{mg} /$ day and appear to be dose-dependent. Complete recovery of spermatogenesis occurs on cessation of the drug, but recovery of the Leydig cells is much slower, which may account for some of the 'cures' claimed for this drug. Other progestagens have similar effects on spermatogenesis (Brotherton, 1972) although the testicular changes may be more severe, increasing in the order of pregnane-type progestagens, e.g. medroxyprogesterone acetate (Camacho, Williams \& Montalvo, 1972), androstane- and oestrane-type progestagens, androgens and oestrogens. With the last two types of compounds, irreversible atrophy and hyalinization tend to occur.

It seems that, in the presence of normal FSH and LH levels, the mechanism of action of cyproterone acetate on the testes is direct. There is probably a direct competition with androgen-binding sites in the testes (Hansson \& Tveter, 1971), which would account for the complete absence of androgenic stimulation of the target organs in the presence of residual significant plasma 
testosterone levels. It is considered that there may also be a site of competitive inhibition at some stage in steroid synthesis after progesterone. Cyproterone acetate is structurally related to progesterone rather than testosterone. Alterations in steroid production by the testes have been shown in a significant decrease in oestradiol production (Fishman \& Geller, 1970) and a large increase in androstenedione levels (Sorcini et al., 1971), indicating interference with biosynthetic pathways.

\section{AGKNOWLEDGMENTS}

I wish to thank most warmly Dr W. R. Butt of the Department of Clinical Endocrinology, The Birmingham and Midland Hospital for Women, for all the hormone assays and the benefit of his erudite advice. Human pituitary $\mathrm{LH}$, batch IRG-2 (24.6.69), was kindly supplied to Dr W. R. Butt by Dr Anne Stockell Hartree.

I wish to thank also Dr A. W. Harcus for making available some of the patients participating in the clinical trial managed by him and the following clinicians and biochemists for providing clinical data and collecting urine and blood samples: Dr T. S. Davies and Mrs P. M. Hill of Llanfrechfa Grange Hospital, Cwmbran, Mon.; Dr E. A. Ritchie and Mr V. Lazelle of St Augustine's Hospital, Chartham Down, near Canterbury, Kent; and Dr F. G. Rooth of Bethlem Royal Hospital, Beckenham, Kent.

I also thank Mr G. Barnard for technical assistance.

\section{REFERENCES}

ANON. (1972) Management of postpubertal mongols. Br, med. F. iv, 227.

Baghdassarian, A., GuYda, H., Johanson, A., Migeon, G. J. \& Blizzard, R. M. (1970) Urinary excretion of radioimmunoassayable luteinising hormone (LH) in normal male children and adults, according to age and stage of sexual development. F. clin. Endocr. Metab. 31, 428.

Bangham, D. R. \& BoRth, R. (1972) Assay of protein hormones related to human reproduction: problems of specificity of assay methods and reference standards. Acta endocr., Copenh. 71, 625.

BRotherton, J. (1972) Bibliography (with review) on the clinical uses of anti-androgens. Bibl. Reprod. 20, 913.

BRotherton, J. \& Harcus, A. W. (1973) Effect of oral cyproterone acetate on urinary FSH and LH levels in adult males being treated for hypersexuality. (Abstract). J. Reprod. Fert. 33, 356.

ButT, W. R. (1972) The iodination of follicle-stimulating hormone and other hormones for radioimmunoassay. 7. Endocr. 55, 453.

BUTT, W. R. \& LYNCH, S. S. (1971) Estimation of urinary gonadotrophins by bioassay and radioimmunoassay. F. Endocr. 51, 393.

Camacho, A. M., Williams, D. L. \& Montalvo, J. M. (1972) Alterations in testicular histology and chromosomes in patients with constitutional sexual precocity treated with medroxyprogesterone acetate. J. clin. Endocr. Metab. 34, 279.

Cooper, A. J., Ismail, A. A. A., Phanjoo, A. L. \& Love, D. L. (1972) Anti-androgen (cyproterone acetate) therapy in deviant hypersexuality. Br. J. Psychiatry, 120, 59.

Croxton, F. E., Cowden, D. J. \& KLeIn, S. (1968) Applied general statistics, 3rd edn, p. 190. Pitman, London.

Faman, C. \& Winter, J. S. D. (1971) Diurnal cycles in plasma FSH, testosterone and cortisol in men. 7. clin. Endocr. Metab. 33, 186.

Fishman, J. \& GeLler, J. (1970) Effect of the antiandrogen cyproterone acetate on estradiol production and metabolism in man. Steroids, 16, 351.

Goldzieher, J. W., Kleber, J. W., Moses, L. E. \& Rathmacher, R. P. (1970) A cross-sectional study of plasma FSH and LH levels in women using sequential, combination or injectable steroid contraceptives over long periods of time. Contraception, 2, 225.

Gordon, G. G., Southern, A. L., Tochimoto, S., Olivo, J., Altman, K., Rand, J. \& Lemburger, L. 
(1970) Effect of medroxyprogesterone acetate (Provera) on the metabolism and biological activity of testosterone. F. clin. Endocr. Metab. 30, 449.

Hansson, V. \& TVETER, K. J. (1971) Effect of anti-androgens on the uptake and binding of androgen by human benign nodular prostatic-hyperplasia in vitro. Acta endocr., Copenh. 68, 69 .

Hemphiml, R. E., REISs, M. \& TAYLOR, A. L. (1944) Study of the histology of the testis in schizophrenia and other mental disorders. F. ment. Sci. 90, 681 .

Johnson, J. (1968) Disorders of sexial potency in the male. Pergamon Press, Oxford.

Kirschner, M. A. \& Schneider, G. (1972) Suppression of the pituitary-Leydig cell axis and sebum production in normal men by medroxy-progesterone acetate. Acta endocr., Copenh. 69, 385.

Kolodny, R. G., Jacobs, L. G., Masters, W. H., Toro, G. \& Daughaday, W. H. (1972) Plasma gonadotrophins and prolactin in male homosexuals. Lancet, ii, 18.

LASCHET, U. \& LASGHET, L. (1967) Antiandrogentherapie der pathologisch gesteigerten und abartigen Sexualität des Mannes. Klin. Wschr. 45, 324.

Laschet, U. \& Laschet, L. (1971) Psychopharmacotherapy of sex offenders with cyproterone acetate. Pharmakopsychiatrie Neuro-Pharmacologie, 4, 99.

Lee, P. A., JAFFe, R. B., Midgley, A. R., KOHEN, F. \& Niswender, G. D. (1972) Regulation of human gonadotrophins. VIII. Suppression of serum LH and FSH in adult males following exogenous testosterone administration. F. clin. Endocr. Metab. 35, 636.

Lee, P. A., Midgley, A. R. \& Jaffe, R. B. (1970) Regulation of human gonadotrophins. VI. Serum FSH and LH determinations in children. J. clin. Endocr. Metab. 31, 248.

MANCini, R. E., VILAR, O., Donini, P. \& LlORET, A. P. (1971) Effect of human urinary FSH and LH on the recovery of spermatogenesis in hypophysectomised patients. F. clin. Endocr. Metab. 33, 888.

Markewitz, M., Veenema, R. J., Fingerhut, B., Nehme-Haily, D. \& Sommers, S. G. (1969) Gyproterone acetate effect on histology and nucleic acid synthesis in the testes of patients with prostatic carcinoma. Investve Urol. 6, 638.

Oтt, F. (1968) Hypersexualität, Andiandrogene und Hodenfunktion. Praxis, 57, 218.

OtT, F. \& Hoffet, H. (1968) Beeinflussung von Libido, Potenz und Hodenfunktion durch Antiandrogene. Schweiz. med. Wschr. 98, 1812.

Peterson, N. T., Midgley, A. R. \& Jafre, R. B. (1968) Regulation of human gonadotrophins. III. Luteinising hormone level and follicle-stimulating hormone in sera from adult males. 7 . clin. Endocr. Metab. 28, 1473.

Raiti, S. M. B., Light, G. \& Blizzard, R. M. (1969) Urinary follicle-stimulating hormone excretion in boys and adult males as measured by radioimmunoassay. F. clin. Endocr. Metab. 29, 884.

Rausch-Strooman, J. G., Petriy, R., Hocevar, V., Mauss, J. \& Senge, T. (1970) Influence of an anti-androgen (cyproterone) on the gonadotrophic function of the pituitary gland, on the gonads and on metabolism in normal men. Acta endocr., Copenh. 63, 595.

Reiter, E. O. \& Kulin, H. E. (1972) Sexual maturation in the female. Normal development and precocious puberty. Pediat. Clins $\mathcal{N}$. Am. 19, 581.

Rosen, S. W. \& WeInTraub, B. D. (1971) Monotropic increase in serum FSH correlated with low sperm count in young men with idiopathic oligospermia and aspermia. F. clin. Endocr. Metab. 32,410 .

Saxena, B. B., Leyendecker, G., Chen, W., Gandy, H. M. \& Peterson, R. E. (1969) Radioimmunoassay of FSH and LH by chromatoelectrophoresis. Acta endocr., Copenh. Suppl. 142, 185.

Schoonezs, R., Schalch, D. S. \& MURPhy, G. P. (1971) The hormonal effects of anti-androgen (SH 714) treatment in man. Investve Urol. 8, 635.

Sorcini, G., Sciarra, F., di Silverio, F. \& Fraioli, F. (1971) Further studies on plasma androgens and gonadotrophins after cyproterone acetate (SH 714). Folia endocr. 24, 196.

STÄDTLER, F. (1972) Histologische Befunde an menschlichen Hodenbiopsien yor und unter Antiandrogenbehandlung. In: Life Sciences Monographs, 2, 101. Ed. G. Raspé. Pergamon Press, Oxford.

Sundsfjord, J. A., AakvaAg, A. \& Norman, N. (1971) Reduced plasma testosterone and LH in young men during progesterone administration. F. Reprod. Fert. 26, 263.

VosBeck, K. \& KELLER, P.J. (1971) The influence of anti-androgens on the excretion of FSH, LH and 17-ketosteroids in males. Hormone metab. Res. 3, 273.

Wikramanayake, R., Keenan, J. R., Spathis, G. S., Nabarro, J. D. N., Leonard, P. J. \& Gallagher, M. J. (1972) Plasma and urinary luteinising hormone levels in the diagnosis of endocrine disease. Br. med. F. i, 775.

YeN, S. S. G. \& TSAI, C. C. (1971) The biphasic pattern in the feedback action of ethinyloestradiol on the release of pituitary FSH and LH. J. clin. Endocr. Metab. 33, 882. 